\title{
A Comparative Study of e-Learning Readiness of Two State Agricultural Universities (SAUs) in Northern India
}

\author{
N. Yogita ${ }^{1 *}$ and M. A. Ansari ${ }^{2}$ \\ Department of Agriculture, Roorkee College of Engineering, Roorkee (Uttarakhand), India \\ *Corresponding author
}

\begin{abstract}
A B S T R A C T
E-learning has acquired centre stage in the changing education landscape in the country. In order to realize the full potential of e-learning, the different stakeholders should be e-ready to partake in the e-learning process. Teachers, students and administrators are three critical stakeholders of an education system. The present study was undertaken to find out the elearning readiness of teachers of two State Agriculture Universities (SAUs) in North India. The two SAUs were selected randomly and the respondents were selected through Stratified random sampling following PPS (Probability Proportionate to Size). The total sample size included 140 teachers, 70 from each of the two selected University. A structured, pre-tested questionnaire was used to collect the data which was analysed using SPSS. E-learning readiness was measured on eight components: Technological Skills Readiness, Online learning style readiness, Infrastructure readiness, Attitude readiness, Human resources readiness, Environmental readiness, Cultural readiness and Financial readiness. Each dimension was measured on a five point continuum. The study findings indicated that average Mean score for each of the two SAUs indicated that the two Universities were "ready but needs improvement". The policy makers, administrators and educationists of higher agriculture education system of the country can draw lessons from the study findings and prepare appropriate plans and strategies and develop a model system to make an SAU e-ready.
\end{abstract}

\section{Introduction}

"The illiterates of the $21^{\text {st }}$ century will not be those who can't read and write, but those who can't learn, unlearn and relearn."-Alvin Toffler

In order to address the changes and challenges in education sector, e-learning has emerged as a new paradigm of teaching-learning process. This new paradigm of modern education in $21^{\text {st }}$ century has comprehensively transformed the education landscape by integrating the use of internet-based information delivery systems and learning management platforms. Thanks to the rapid advancements in Information and Communication Technologies (ICTs) coupled with gradual \& regulated expansion of telecommunication sector, the increasing adoption of e-learning in higher educational institutions is gaining momentum in India as well as globally. The 
chief stakeholders-students, teachers and administrators are fully aware of its importance in enhancing the learning outcomes (Navani and Ansari, 2017). Use of educational technology has become necessary in order to succeed and achieve the dream of an educated and competent workforce. The crucial need for students is to focus on importance of lifelong learning, i.e. to continuously upgrade their knowledge and skills, to think critically and to inspire creativity and innovation so as to adapt to global change (UNESCO, 2004). Advances in Information and Communication Technology have led to radical changes in the way education is being imparted. Evolution of internet and advancement in information and communication technology has led to emergence of new approaches in teaching, learning and training.

Ansari and Navani (2019) emphasized that eLearning combines online component with the conventional face to face components. It is now an alternative mode of teaching and learning in higher education in the country. Technology does not have an educational value in itself until it is incorporated in the teaching-learning process, either in classroom or outside. Higher education institutes /universities are now motivated to include eLearning courses as an alternative method in education. E-learning has changed the dynamics of teaching-learning process, and playing an ever-increasing and important role in restructuring higher education. It is the technology which lets the learner learn through instruction, education and training via internet over a distance. Tahereh et al., (2010) observed that e-learning as a solution, the possibility of widespread use, access and sharing of knowledge unmatched by other types of instruction delivery. Here, the students have access to much richer sources of information than the teacher - the internet resources and the vast amount of expertise available online. It is actually changing the way how teachers teach and students learn. Further, Navani and Ansari (2020) asserted that education landscape has been comprehensively transformed by the use of internet-based information delivery systems and learning management platforms. Thanks to the rapid advancements in Information and Communication Technologies (ICTs) coupled with gradual \& regulated expansion of telecommunication sector, the increasing adoption of e-learning in higher educational institutions is gaining momentum in India as well as globally. The chief stakeholdersstudents, teachers and administrators-are fully aware of its importance in enhancing the learning outcomes

E-learning represents an innovative shift in the field of teaching-learning, providing rapid access to specific knowledge and information, and offers online instruction that can be delivered anytime and anywhere through a wide range of electronic learning solutions such as a web-based courseware and online discussion groups. Higher education institutes/ universities are now motivated to include e-learning courses as an alternative method in education. But teachers as well as students/learners are not prepared as well as reluctant to take up e-learning. This is due to the insufficiency or absence of computer related basic skills or the anxiety in using technology in education. So, researches need to be conducted for analyzing the readiness of stakeholders in universities whether they are e-ready in the uptake of e-learning.

\section{Definition of e-Learning}

The e-learning refers to learning with use of communication and information technologies. There are many definitions given to elearning. Liaw et al., (2007) define e-learning as the convergence of technology and learning, and the use of network technologies 
to facilitate learning anytime, anywhere. Davis (2001) describes e-learning as technology-enabled learning that covers various concepts, or a phenomenon delivering instructions through technology. Further, elearning is a process of education (learning and teaching process) conducted using the information and communication technology which improves the quality of the process itself and the quality of its result. In other words, e-learning eases the process of learning and teaching through faster and convenient content delivery and reaching the large number of client learners in a short duration of time. It helps in enhancing the quality of education imparted because of the availability and delivery of upto date and correct information through computer networks and electronic media. Usage of new technologies, internet and e-learning in higher education especially in teacher education programs, can enhance the speed of development and educate citizen at a higher speed and fulfills demands of living in $21^{\text {st }}$ century.

Welsh et al., (2003) define e-learning as the use of computer network technology through the Internet to deliver information and instruction to learners. Rosenberg (2001) refers to e-learning as using Internet technologies to deliver various solutions to learners.

The e-learning systems are a kind of technological developments that have reformed and restructured the delivery and interaction of students and teachers with course materials and related resources. The elearning systems have been widely used in developed countries and have recently become more common in many developing countries. The importance of electronic media can't be ignored for many reasons. It can play a critical role in equipping modern university teachers with sophisticated and innovative learning tools.

\section{The e-learning readiness}

The e-learning is viewed as an instrument expanding the access and reach of education services beyond the four-walls of classroom. It has emerged as a tool for providing opportunities for marginalized and disadvantaged students or those who are unable to attend classes due to physical, social and economic constraints. E-learning is identified as a alternative mode of content delivery involving the effective utilisation of the internet and integrating technology in education that provides participants with network technology enabling them to communicate, share, cooperate and interact with each other. Borotis and Poulymenakou (2004) defined it as "the mental or physical preparedness of an organization for some elearning experience or action".

Readiness includes learners' awareness and ability to adapt to technological challenges, collaborative learning in synchronous as well as asynchronous modes. Readiness for an organization intending to adopt e-learning can be defined as the "mental or physical (infrastructural) preparedness for that organization for some e-learning experience or action". It is important to comprehend that readiness can't take only binary values; rather it is a continuous process.

Machado (2007) explained e-readiness in context of higher education as "the ability of Higher Education Institutes (HEIs) and the capacity of institutional stakeholders to generate learning opportunities by facilitating computer-based technologies." An 'e-ready' society/ institution may be said to have the necessary physical infrastructure, integrated with current ICTs throughout businesses (ecommerce, e-services, local ICT sector), communities (local content, organizations being online, ICTs used in everyday life, ICTs taught in schools), and the government (e- 
governance), and no limits on trade or foreign investment. The importance of e-learning has led to the need in assessing the mental and physical preparation of the users before using the e-learning environment. Therefore, elearning readiness is required in making sure the users are capable of using the e-learning environment technology in the best way possible. Technically speaking, e-learning readiness is the capability of prospective elearning users in using a new learning environment as well as the usage of alternative technology.

\section{Role of e-learning in higher education}

Neeru (2009) reported about the transformation of higher education in the country in terms of access, equity and quality due to increased usage of ICTs in education. Therefore, integration of ICT into teaching and learning process will empower teachers to focus on student-centered approach, active and interactive learning, connecting with learner experiences and needs, and development of critical and ethical understandings of the value of the use of ICT. Institutions of higher learning and universities must incorporate ICTs (online and offline) for imparting educational content in order to make learning effective. Broadcast and interactive technologies can also be used in technology facilitated education so that even the vulnerable groups can pursue education.

The increasing influence of globalization and the emerging information society has set new requirements for all areas of social life, including higher education. Hence, e-learning has become an important instrument in the new higher educational environment in the digital age which creates student-centered learning and educational practice, offering more flexible learning environment. The concept of e-learning is still vague to many of us in India. E-learning is essentially electronic learning and is delivered online through a computer or any other electronic gadget such as smart phone, tablet, PDAs etc. In different sectors and with different people, the meaning of e-learning differs. For instance, in the field of business it refers to the strategies used by a company network to give training to its employees. In many Universities, the term is used to mean a specific method to convey contents of course or program to the students online. Many higher education instructions nowadays are offering e-learning to their students. In fact, e-learning is a useful medium through which India can attain the goal of reaching the unreached in rural areas, motivating the learners for higher education as well as achieve the goals of woman empowerment through their education. In this current era of networked economy and globalised world, education needs to meet the additional demands of present time such as creating globally competent work force. According to a recent study in a global level online learning program, after the United States, India has been reported to have the second highest number of online course enrollments with over 1,55,000 students from the country. Around 1.2 million students worldwide, $32 \%$ are from the U.S while $15 \%$ are from India. According to All India Survey on Higher Education (2011-12), Gross Enrolment Ratio (GER) in Higher education in India is 20.4, which is calculated for 18- 23 years of age group. Yuen (2010) reported that e-learning has the potential to overcome the non availability of adequately qualified teachers in rural India.

In the present study, e-learning readiness shall be defined for university teachers. The elearning readiness will be reflected in the readiness of learners' readiness (intended/ targeted) for the acceptance of new technology in education. However, it presupposes the availability of infrastructure, clear learning objectives, teacher/trainer 
support and guidance and knowledgeable leadership. The e-learning readiness of University faculty in this study shall include their readiness to integrate the latest ICTs in the classroom situations, technical competency in educational content management (e.g. designing and uploading educational content on the web, online supervision and evaluation systems, etc) and their attitude towards e-learning as a mode of instruction. The e-learning readiness can be assessed by evaluating an individual's technical experience and competency in handling computers. Organisations have to be ready to adopt e-learning and benefit from its advantages. Such e-readiness can be defined as "how ready the organisation is on several aspects to implement e-learning".

Hence the present study was undertaken with the following objectives include to find out socio-personal and psychological characteristics of teachers of SAUs. To assess the e-learning readiness of teachers of selected SAUs. To compare the e-learning readiness of teaches of two SAUs. Also to study the relationship between selected sociopersonal and psychological characteristics of teachers of SAUs with their respective eLearning readiness.

\section{Materials and Methods}

The present study intended to determine and compare the e-learning readiness of two randomly selected State Agriculture Universities (SAUs) of North India, i.e. Govind Ballabh Pant University of Agriculture and Technology (GBPUAT), Pantnagar, Uttarakhand (hereinafter referred as SAU-1) and Chaudhary Sarwan Kumar Himachal Pradesh Krishi Vishvavidyalaya (CSK HPKV), Palampur, Himanchal Pradesh (hereinafter referred as SAU-2). Among the various faculties of the two SAUs, Agriculture faculty was considered for inclusion in the sampling frame.

The study sample comprised of teachers of the two selected SAUs and intended to include the teachers of the three designations, i.e. Assistant Professors, Associate Professors and Professors. In order to give due representation to all the three designations in the study sample, Stratified random sampling (with PPS) was followed.

On the basis of designation of different teachers in the University, three strata were formed. Assistant Professors or equivalent constituted the first stratum, Associate Professors or equivalent constituted the second strata and Professors or equivalent constituted the third strata.

Following stratified random sampling with PPS (Probability proportional to size) the study sample was selected I the following manner.

$\mathrm{n}_{\mathrm{h} 1}=\left(\mathrm{N}_{\mathrm{h} 1} / \mathrm{N}\right) * \mathrm{n}$

where,

$\mathrm{n}_{\mathrm{h} 1}=$ sample size for stratum $\mathrm{h} 1$

$\mathrm{N}_{\mathrm{h} 1}=$ population size for stratum $\mathrm{h} 1$

$\mathrm{N}=$ total population size

$\mathrm{n}=$ total sample size

In the Faculty/ College of Agriculture, GBPUAT, Pantnagar consisted of three different strata $h 1, h 2$ and $h 3$

$\mathrm{h} 1=$ Assistant professor;

$\mathrm{h} 2=$ Associate professor;

h3= Professor

$\mathrm{N}_{\mathrm{h} 1}=74 ; \mathrm{N}=192 ; \mathrm{n}=70$

$\mathrm{n}_{\mathrm{h} 1}=(74 / 192) * 70=26.9=27$

$\mathrm{n}_{\mathrm{h} 2}=(9 / 192) * 70=3.28=3$

$\mathrm{n}_{\mathrm{h} 3}=(109 / 192) * 70=39.7=40$

$\mathrm{n}=\mathrm{n}_{\mathrm{h} 1+} \mathrm{n}_{\mathrm{h} 2+} \mathrm{n}_{\mathrm{h} 3}=27+3+40=70$ 


\begin{tabular}{|l|c|c|}
\hline \multirow{2}{*}{$\begin{array}{l}\text { Respondent } \\
\text { Categories } \\
\text { (GBPUAT) }\end{array}$} & $\begin{array}{c}\text { No. of } \\
\text { teachers }\end{array}$ & $\begin{array}{c}\text { Total= } \\
\mathbf{7 0}\end{array}$ \\
\cline { 2 - 3 } & $\begin{array}{c}\text { Population } \\
\text { size }\end{array}$ & $\begin{array}{c}\text { Sample } \\
\text { size }\end{array}$ \\
\hline $\begin{array}{l}\text { Assistant Professor or } \\
\text { equivalent }\end{array}$ & 74 & 27 \\
\hline $\begin{array}{l}\text { Associate Professor or } \\
\text { equivalent }\end{array}$ & 9 & 3 \\
\hline Professor or equivalent & 109 & 40 \\
\hline
\end{tabular}

Similarly, faculty members in College of Agriculture, HPKV, Palampur comprised of three different strata - h1, h2 and h3

$\mathrm{h} 1=$ Assistant professor; $\mathrm{h} 2=$ Associate professor; $\mathrm{h} 3=$ Professor

$\mathrm{N}_{\mathrm{h} 1}=3 ; \mathrm{N}=83 ; \mathrm{n}=70$

$\mathrm{n}_{\mathrm{h} 1}=(3 / 83) * 70=2.53=2$

$\mathrm{n}_{\mathrm{h} 2}=(15 / 83) * 70=12.65=13$

$\mathrm{n}_{\mathrm{h} 3}=(65 / 83) * 70=54.8=55$

$\mathrm{n}=\mathrm{n}_{\mathrm{h} 1+} \mathrm{n}_{\mathrm{h} 2}+\mathrm{n}_{\mathrm{h} 3} \quad=\mathbf{2 + 1 3 + 5 5}=\mathbf{7 0}$

\begin{tabular}{|l|l|l|}
\hline \multirow{2}{*}{$\begin{array}{l}\text { Respondent } \\
\text { Categories } \\
\text { (CSKHPKV) }\end{array}$} & $\begin{array}{l}\text { No. of } \\
\text { teachers }\end{array}$ & $\begin{array}{l}\text { Total= } \\
\mathbf{7 0}\end{array}$ \\
\cline { 2 - 3 } & $\begin{array}{l}\text { Population } \\
\text { size }\end{array}$ & $\begin{array}{l}\text { Sample } \\
\text { size }\end{array}$ \\
\hline $\begin{array}{l}\text { Assistant Professor or } \\
\text { equivalent }\end{array}$ & 3 & 2 \\
\hline $\begin{array}{l}\text { Associate Professor or } \\
\text { equivalent }\end{array}$ & 15 & 13 \\
\hline Professor or equivalent & 65 & 55 \\
\hline
\end{tabular}

Overall, the study sample consisted of 29 Assistant Professor, 15 Associate Professors and 95 Professors; and total sample size was 140. The study sample may look little heavy/ disproportionate, but we had to depend on the existing strength of the three cadres of teachers as many posts of the three different cadres were lying vacant. A structured and pre-tested questionnaire was done for collection of data and it was analysed using SPSS.

After the careful review of the relevant researches, the independent variables (i.e.
Socio-personal and Psychological variables) included in the study were: Age, Gender, Educational qualification, Designation, Annual income, Teaching experience, Formal social participation, Computer literacy, Achievement motivation, Access to internet facility, Membership of social networking sites, Mobile phone ownership and use, Perceived usefulness, Perceived ease of use, Attitude towards e-learning. Further, the elearning readiness was the lone dependent variable. The e-learning readiness of teachers of the two SAUs was measured by using the modified framework developed by Mutiaradevi (2009) on eight dimensions: Technological Readiness, Online Learning style readiness, Infrastructure readiness, Attitude readiness, Human Resource Readiness, Environmental Readiness, Cultural Readiness and Financial readiness. An elaborate schedule was administered. Further, to determine e-learning readiness of State Agricultural Universities, Aydın and Taşçı's (2005) e-learning assessment model was adopted. It clearly mentions the expected level of e-learning readiness on a five-point continuum, i.e. the Mean Score of 3.41 is normally taken as the expected level of readiness. Lower or higher Mean score can also be interpreted as shown in the figure below.

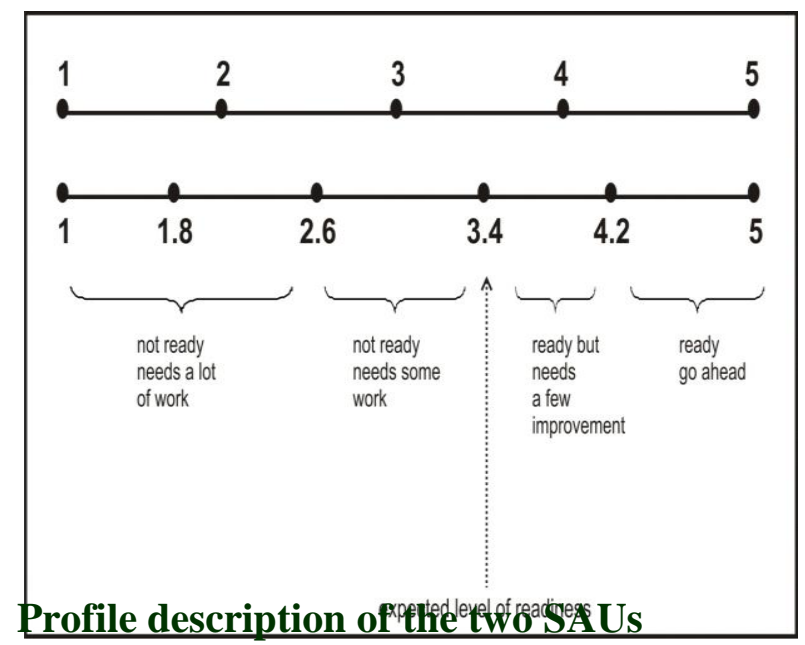




\section{SAU-1 (GBPUAT, Pantnagar)}

Established in 1960 as the first agricultural university of India on land grant pattern of USA, it was inaugurated by country's first Prime Minister, Mr. Jawaharlal Nehru. Eulogised as the "harbinger of Green Revolution in India" by Nobel Laureate Norman E. Borlague, the University has been awarded twice as the Best Agriculture Institution in India by Indian Council of Agriculture Research (ICAR), in 1997 and 2005. The University is known as having the single largest campus in India, situated in the district of Udham Singh Nagar of Uttarakhand.

The University has seven constituent colleges (faculties) and offers a number of UG, PG and Ph.D. programmes in the disciplines of Agriculture, Home Science, Veterinary \& Animal Sciences, Basic Sciences \& Humanities, Agribusiness Management, Fishery Sciences, and Engineering/ Technology. College of Agriculture is the largest academic unit of the University and offer two flagship UG programmes - B.Sc. Agriculture and B. Sc. Food Sciences and Technology. It has a dynamic and innovative and industry-ready education programmes to meet the modern challenges of scientific manpower, vital and relevant research and effective extension services.

Presently, it has eleven departments, namely Agricultural Communication, Agricultural Economics, Agrometerology, Agronomy, Vegetable Science, Food Science \& Technology, Horticulture, Soil Science, Genetics \& Plant Breeding, Entomology, and Plant Pathology. It has a sanctioned strength of around 200 teachers.

\section{SAU-2 (CSK HPKV, Palampur)}

Initially known as Himachal Pradesh Krishi
Vishwavidyala (HPKV), it has recently been renamed as Chaudhary Sarwan Kumar Himachal Pradesh Krishi Vishvavidyalaya (in June, 2001). It was established on $1^{\text {st }}$ November, 1978 as an expansion of the existing College of Agriculture (established in May, 1966, and initially a part of the old Panjab Agriculture University, Ludhiana). The College of Agriculture, Palampur formed the nucleus of the new agriculture university (HPKV).

Over the years, the University has contributed significantly in transforming the farm scenario in Himachal Pradesh. Today, the State has earned its name for hill agricultural diversification and the farming community has imposed its faith in the University. The University is known for its innovations in hill agriculture and is widely credited for transforming the agriculture scenario in the state. It offers a number of UG, PG and Ph. D. degree programmes in various subjects of agriculture.

The College of Agriculture at CSK-HPKV has 13 departments, viz., Agricultural Biotechnology, Agricultural Economics, Extension Education and Rural Sociology, Agricultural Engineering, Agronomy, Forage and Grassland Management, Crop Improvement, Entomology, Horticulture, Organic Agriculture, Plant Pathology, Seed Science \& Technology, Soil Science, Tea Husbandry \& Technology, Vegetable Science $\&$ Floriculture.

\section{Results and Discussion}

The results of the present study are presented in the form of following tables.

\section{Socio-personal and psychological characteristics of University teachers}

The results obtained in respect of profile 
characteristics of the respondents are given in Table-1.

A careful perusal of the results presented in table-1 reveals that that majority of teachers in the two SAUs were middle aged; $61.43 \%$ (SAU-1) \& 72.83\% (SAU-2). Gender wise composition of the respondents reveals that majority were males $-65.71 \%$ in SAU-1 and $81.42 \%$ in SAU-2. As regards educational qualifications of the respondents, a large majority of them - 95.71\% in SAU-1 and $82.85 \%$ in SAU-2 were $\mathrm{Ph}$. D. holders. Further, it was found that majority $(38.57 \%)$ of teachers in SAU-1 were in high income category whereas in SAU-1 majority $(60 \%)$ were in medium category of annual income earned by them. Regarding teaching experience, majority of them $(37.14 \%$ in SAU-1 and $57.14 \%$ in SAU-2) had about 5-23 years of experience. Additionally, $40 \%$ in SAU-1 \& $11.42 \%$ in SAU-2 had less than five years of teaching experience although $22.85 \%$ and $31.42 \%$ had high teaching experience in both the SAUs, respectively.

Further, regarding computer literacy of University teachers which is of crucial importance in e-e-learning readiness, it was found that majority of the teachers $68.57 \%$ and $78.57 \%$ of the teachers had medium level of computer literacy followed by $4.42 \%$ $\& 14.28 \%$ of teachers who had low computer literacy, and the remaining $20 \% \& 7.14 \%$ of teachers had high level of computer literacy in both the SAUs, respectively.

Achievement motivation of teachers is very critical in implementing the e-learning programmes in any education institution. The data in the above table reveals that majority of teachers $-54.28 \%$ in SAU-1 \& 70\% in SAU2- had medium level of achievement motivation followed by $22.85 \%$ and $15.71 \%$ of teachers who had low levels of achievement motivation and the remaining
$22.85 \%$ and $8.57 \%$ of teachers displayed high levels of achievement motivation in both the SAUs, respectively.

Access to internet is another critical factor in implementing e-learning programmes in an educational institution. The results obtained also reveals that majority of the teachers $84.29 \%$ in SAU-1 and $68.57 \%$ in SAU-2 had internet connection both at their office as well as home. Remaining $31.42 \%$ \& $15.71 \%$ of teachers had internet connection only in their offices in both the SAUs respectively.

\section{E-learning readiness of universities}

In the present study, e-learning readiness of teachers of two SAUs was measured using an instrument developed by Retisa Mutiaradevi (2009) comprising eight indicators: (1) technological skills; (2) infrastructure availability; (3) online learning style; (4) attitude; (5) human resources; (6) cultural; (7) environmental; and (8) financial. Each of these indicators included had several statements formulated to get the response of teachers included in the study sample. The responses were then coded, categorised and analysed using appropriate statistical techniques. Further, in order to determine elearning readiness of the two SAUs, Aydin and Taşçı's (2005), e-learning assessment model was adopted. The findings regarding elearning readiness of University teachers are presented in Table-2

Findings presented in the above table indicate that overall Mean score for SAU-1 (i.e. GBPUAT) and HPKV (SAU-2) were worked out to be is 3.73 and 3.68, respectively. As per the e-learning framework of Aydin and Tasci (2007), this can be interpreted as "ready but needs few improvement" for both the SAUs. However, when assessed on each of the eight constituent dimensions of e-learning readiness of teachers of SAUs, i.e. Technological Skills 
Readiness (Mean Score $=4-19$ and 3.98), Online learning style readiness (Mean Score = 2.54 and 2.48), Infrastructure readiness (Mean=4.32 and 4.29), Attitude readiness (Mean=3.44 and 4.01), Human resource readiness (Mean=2.68 and $2.82 \quad$ ), Environmental readiness (Mean $=4.13$ and 4.01), Cultural readiness (Mean $=3.59$ and 3.39 ) and Financial readiness (Mean $=4.99$ and 4.11 ) for SAU-1 and SAU-2, respectively.

It can thus be concluded that this SAU-2
(CSK-HPKV) is not ready in only one component i.e. human resource readiness which is below the expected minimum level and the remaining seven constituents are above the minimum expected level of elearning readiness. Further, it can be concluded that SAU-1 (GBPUAT) is not ready in two dimensions i.e. online learning style readiness and human resource readiness which is below the expected minimum level and the remaining six constituents are above the minimum expected level of e-learning readiness.

Table.1 Socio-personal and psychological characteristics of the teachers of two SAUs

\begin{tabular}{|c|c|c|c|c|c|c|}
\hline \multirow{2}{*}{$\begin{array}{l}\text { SI. } \\
\text { No. }\end{array}$} & \multirow{2}{*}{$\begin{array}{l}\text { Independent } \\
\text { variables }\end{array}$} & \multirow[t]{2}{*}{ categories } & \multicolumn{2}{|c|}{ SAU-1 } & \multicolumn{2}{|c|}{ SAU-2 } \\
\hline & & & Frequency & percentage & Frequency & percentage \\
\hline \multirow[t]{3}{*}{1} & \multirow{3}{*}{ Age } & Young $(<36)$ & 19 & 27.14 & 13 & 18.57 \\
\hline & & Middle(36-55) & 43 & 61.43 & 51 & 72.85 \\
\hline & & Old $(>55)$ & 8 & 11.43 & 6 & 8.58 \\
\hline \multirow[t]{2}{*}{2} & \multirow[t]{2}{*}{ Gender } & Male & 46 & 65.71 & 57 & 81.42 \\
\hline & & Female & 24 & 34.28 & 13 & 18.57 \\
\hline \multirow[t]{3}{*}{3} & \multirow{3}{*}{$\begin{array}{l}\text { Educational } \\
\text { qualification }\end{array}$} & Masters & 0 & 0 & 11 & 15.71 \\
\hline & & Ph.D & 67 & 95.71 & 58 & 82.85 \\
\hline & & Post Doc & 3 & 4.28 & 1 & 1.42 \\
\hline \multirow[t]{3}{*}{4} & \multirow[t]{3}{*}{ Annual income } & Low $(<6,25,556.7)$ & 28 & 40 & 17 & 24.28 \\
\hline & & $\begin{array}{l}\text { Medium } \\
11,38,245.0)\end{array}(6,25,556.7-$ & 15 & 21.42 & 42 & 60 \\
\hline & & High $(>11,38,245.00)$ & 27 & 38.57 & 11 & 15.71 \\
\hline \multirow[t]{3}{*}{5} & \multirow{3}{*}{$\begin{array}{l}\text { Teaching } \\
\text { experience }\end{array}$} & Low $(<5$ yrs $)$ & 28 & 40 & 8 & 11.42 \\
\hline & & Medium(5-23 yrs) & 26 & 37.14 & 40 & 57.14 \\
\hline & & High (>23 yrs) & 16 & 22.85 & 22 & 31.42 \\
\hline \multirow[t]{3}{*}{6} & \multirow{3}{*}{$\begin{array}{l}\text { Computer } \\
\text { literacy }\end{array}$} & Low $(<56.2)$ & 8 & 4.42 & 10 & 14.28 \\
\hline & & Medium(56.2-75) & 48 & 68.57 & 55 & 78.57 \\
\hline & & $\operatorname{High}(>75)$ & 14 & 20 & 5 & 7.14 \\
\hline \multirow[t]{3}{*}{7} & \multirow{3}{*}{$\begin{array}{l}\text { Achievement } \\
\text { motivation }\end{array}$} & Low $(<17.16)$ & 16 & 22.85 & 15 & 21.42 \\
\hline & & Medium(17.16-29.58) & 38 & 54.28 & 49 & 70 \\
\hline & & High $(>29.58)$ & 16 & 22.85 & 6 & 8.57 \\
\hline \multirow[t]{2}{*}{8} & \multirow{2}{*}{$\begin{array}{l}\text { Access to } \\
\text { internet facility }\end{array}$} & office & 11 & 15.71 & 22 & 31.42 \\
\hline & & Both (office and home) & 59 & 84.29 & 48 & 68.57 \\
\hline
\end{tabular}

SAU-1 = GBPUAT; SAU-2 = CSKHPKV 
Table.2 E-learning readiness of teachers of two SAU

\begin{tabular}{|c|c|c|c|c|c|}
\hline \multirow{2}{*}{$\begin{array}{l}\text { Sl. } \\
\text { No. }\end{array}$} & \multirow{2}{*}{$\begin{array}{l}\text { E-learning } \\
\text { Readiness } \\
\text { component }\end{array}$} & \multicolumn{2}{|r|}{ SAU-1 } & \multicolumn{2}{|r|}{ SAU-2 } \\
\hline & & Mean & comments & Mean & Comments \\
\hline 1 & $\begin{array}{c}\text { Technological Skills } \\
\text { Readiness }\end{array}$ & 4.19 & Ready go ahead & 3.98 & $\begin{array}{l}\text { Ready but needs } \\
\text { few improvements }\end{array}$ \\
\hline 2 & $\begin{array}{l}\text { Online learning } \\
\text { style readiness }\end{array}$ & 2.54 & $\begin{array}{l}\text { Not ready needs a } \\
\text { lot of work }\end{array}$ & 2.48 & $\begin{array}{l}\text { Not ready needs a } \\
\text { lot of work }\end{array}$ \\
\hline 3 & $\begin{array}{l}\text { Infrastructure } \\
\text { readiness }\end{array}$ & 4.32 & Ready go ahead & 4.29 & Ready go ahead \\
\hline 4 & Attitude readiness & 3.44 & $\begin{array}{l}\text { Ready but needs } \\
\text { few } \\
\text { improvements }\end{array}$ & 4.01 & $\begin{array}{l}\text { Ready but needs } \\
\text { few improvements }\end{array}$ \\
\hline 5 & $\begin{array}{l}\text { Human resources } \\
\text { readiness }\end{array}$ & 2.68 & $\begin{array}{l}\text { Not ready needs } \\
\text { some work }\end{array}$ & 2.82 & $\begin{array}{l}\text { Not ready needs } \\
\text { some work }\end{array}$ \\
\hline 6 & $\begin{array}{l}\text { Environmental } \\
\text { readiness }\end{array}$ & 4.13 & $\begin{array}{l}\text { Ready but needs } \\
\text { few } \\
\text { improvements }\end{array}$ & 4.06 & $\begin{array}{l}\text { Ready but needs } \\
\text { few improvements }\end{array}$ \\
\hline 7 & Cultural readiness & 3.59 & $\begin{array}{c}\text { Ready but needs } \\
\text { few } \\
\text { improvements }\end{array}$ & 3.39 & $\begin{array}{l}\text { Expected level of } \\
\text { readiness }\end{array}$ \\
\hline 8 & Financial readiness & 4.99 & Ready go ahead & 4.41 & Ready go ahead \\
\hline & $\begin{array}{l}\text { Mean Scores } \\
\text { Average }\end{array}$ & 3.73 & $\begin{array}{c}\text { Ready but needs } \\
\text { few } \\
\text { improvements }\end{array}$ & 3.68 & $\begin{array}{l}\text { Ready but needs } \\
\text { few improvements }\end{array}$ \\
\hline
\end{tabular}

Table.4 Correlation Analysis of socio-personal and psychological variables with e-learning readiness of two SAUs

\begin{tabular}{|c|c|c|}
\hline \multirow{2}{*}{ Independent variables } & \multicolumn{2}{|c|}{ E-learning Readiness } \\
\cline { 2 - 3 } & SAU-1 & \multicolumn{1}{c|}{ SAU-2 } \\
\hline Age & $-0.462^{* *}$ & $-0.389^{* *}$ \\
\hline Gender & 0.073 & 0.023 \\
\hline Annual Income & $0.542^{* *}$ & $0.406^{* *}$ \\
\hline Teaching Experience & $-0.286^{*}$ & $-0.305^{*}$ \\
\hline Educational Qualification & $-0.653^{* *}$ & $-0.725^{* *}$ \\
\hline Computer Literacy & $0.538^{* *}$ & $0.694^{* *}$ \\
\hline Designation & $-0.685^{* *}$ & $-0.827^{* *}$ \\
\hline Achievement Motivation & $0.392^{* *}$ & $0.515^{* *}$ \\
\hline Formal Social Participation & $-0.584^{* *}$ & -0.851 \\
\hline Attitude towards e-learning & $0.285^{*}$ & $0.334^{*}$ \\
\hline
\end{tabular}

(*significant at 0.01 level of probability, $* *$ significant at 0.05 level of probability) 
Table.5 Regression analysis between socio-personal and psychological characteristics and elearning readiness of teachers of SAUs

\begin{tabular}{|c|c|c|c|}
\hline \multirow{2}{*}{$\begin{array}{l}\text { Sl. } \\
\text { No. }\end{array}$} & \multirow{2}{*}{$\begin{array}{l}\text { Independent } \\
\text { variables }\end{array}$} & $\begin{array}{c}\text { TER } \\
\text { SAU-1 }\end{array}$ & $\begin{array}{c}\text { TER } \\
\text { SAU-2 }\end{array}$ \\
\hline & & $\begin{array}{c}\text { Partial regression } \\
\text { coefficient (b) }\end{array}$ & $\begin{array}{c}\text { Partial regression } \\
\text { coefficient (b) }\end{array}$ \\
\hline 1. & Age & $\begin{array}{c}0.06 \\
(0.68)\end{array}$ & $\begin{array}{c}\text { 0.16 } \\
(\mathbf{1 . 5 9 )}\end{array}$ \\
\hline 2. & Gender & $\begin{array}{c}2.60 \\
(1.48)\end{array}$ & $\begin{array}{c}-0.91 \\
(0.50)\end{array}$ \\
\hline 3. & Annual Income & $\begin{array}{c}0.02 \\
(1.05)\end{array}$ & $\begin{array}{l}-0.03 \\
(1.48)\end{array}$ \\
\hline 4. & Teaching Experience & $\begin{array}{c}0.10 \\
(1.28)\end{array}$ & $\begin{array}{l}-0.02 \\
(0.03)\end{array}$ \\
\hline 5. & $\begin{array}{l}\text { Educational } \\
\text { Qualification }\end{array}$ & $\begin{array}{c}1.13 \\
(0.69)\end{array}$ & $\begin{array}{c}1.95 \\
(1.36)\end{array}$ \\
\hline 6. & Computer Literacy & $\begin{array}{c}0.02 \\
(0.29)\end{array}$ & $\begin{array}{c}0.06 \\
(0.94)\end{array}$ \\
\hline 7. & Designation & $\begin{array}{c}0.03 \\
(0.03)\end{array}$ & $\begin{array}{l}-0.72 \\
(1.26)\end{array}$ \\
\hline 8. & $\begin{array}{l}\text { Achievement } \\
\text { Motivation }\end{array}$ & $\begin{array}{c}0.07 \\
(0.47)\end{array}$ & $\begin{array}{c}0.07 \\
(0.44)\end{array}$ \\
\hline 9. & $\begin{array}{l}\text { Formal Social } \\
\text { Participation }\end{array}$ & $\begin{array}{c}2.27 \\
(2.55)\end{array}$ & $\begin{array}{c}0.62 \\
(0.83)\end{array}$ \\
\hline 10. & $\begin{array}{c}\text { Attitude Towards e- } \\
\text { learning }\end{array}$ & $\begin{array}{c}0.04 \\
(0.78)\end{array}$ & $\begin{array}{c}-0.08 \\
(0.81)\end{array}$ \\
\hline & & $\mathrm{R}^{2}=.385$ & $\mathrm{R}^{2}=.355$ \\
\hline
\end{tabular}

( $\mathrm{t}$-values are given in parenthesis; $\mathrm{R}^{2}=$ Coefficient of Determination)

Relationship between e-learning readiness of SAUs with socio-personal and psychological characteristics of teachers

The study also intended to find out the relationship between e-learning readiness of SAUs (dependent variable) with sociopersonal \& psychological characteristics (independent variables) of the teachers of the two SAUs. The results obtained are given in table-3 \& 4.

It is evident from the above table that age, teaching experience, educational qualification, designation and formal social participation had negative and significant correlation with dependent variable (elearning readiness) whereas gender, annual, computer literacy, achievement motivation and attitude towards learning had positive and significant correlation with e-learning readiness. Thus we can conclude that younger teachers, having less teaching experience, less educational qualification and less social participation were expected to be more ready for e-learning. It is on expected line as those teachers who are older normally not positively inclined towards e-learning; older generation is expected to have more teaching experience, higher educational qualification, 
and less frequent social interaction. Koo (2008) revealed that individuals' language, discipline, experience in using e-mail and skill levels may affect learners' readiness for e-learning. Navani and Ansari (2016, 2017, 2019, 2020) while studying e-learning readiness of faculty of State Agriculture Universities reported similar results. Deniz (2007) also reiterated that teachers' readiness and positive disposition is more effective for e-learning than just ICT integration in education.

Further, regression analysis was also done to find out the impact of independent variables on the dependent variable. The results obtained are given in Table-5 below.

The results obtained in respect of regression analysis indicate that $\mathrm{t}$-value was not found to be significant for any of the ten independent variables included. The coefficient of determination (R2) for SAU-1 was 0.385, and for SAU-2 it was 0.355. This indicated that all the variables put together could predict only $38.5 \%$ variation in SAU-1 and $35.5 \%$ variation in case of SAU-2. Thus, it can be concluded that the remaining contribution in the e-learning readiness of the teachers of the two SAUs under study was contributed by other factors/ variables not included in the study. They may also be extraneous or intervening variables, which need to be studied further.

In conclusion, the e-learning is fast gaining acceptance worldwide as a powerful tool offering significant advantages over classical face-to-face learning systems. It is enhancing the competitiveness of educational institutions and enabling them to improve the quality and expand reach of their services. In order to adopt e-learning as an alternative tool in higher educational institutions, we need to ascertain the e-learning readiness of educational institutions and its different stakeholders - teachers, students and educational administrators. The present study has attempted to assess e-learning readiness of two state agriculture universities in India. The results of the study indicated that the two SAUs under study are 'not fully ready to adopt e-learning systems and needs few improvements'. The study findings revealed that teachers of these SAUs have shown that age, teaching experience, computer literacy, achievement motivation and attitude towards e-learning are positively correlated with elearning readiness; and surprisingly gender difference didn't affect their e-learning readiness. The educationists, policy makers and researchers should take a note of the findings while planning formulating of $\mathrm{e}$ learning strategies in higher education institutions.

\section{References}

Davis, S. 2001. What e-Learning Can Learn from History. USDLA Journal, 15(10) :644-659.

Deniz, L. 2007. Prospective class teachers' computer experience and computer attitude. International Journal of Social Sciences, 2(2):116-122.

Koo, A. 2008. Factors affecting teachers' perceived readiness for online collaborative learning: A case study in Malaysia. Educational Technology \& Society, 11:266-278.

Liaw, S., Huang, H., and Chen, G. 2007. Surveying Instructor and Learner Attitudes toward e-Learning. Computers \& Education, 49 (4):1066-1080.

Machado, C. 2007. Developing an e-readiness model for higher education institutions: results of a focus group study. British Journal of Educational Technology, 38(1): 72-82.

Navani, Yogita and Ansari, MA. 2016. A study of e-learning readiness of University faculty. International Journal of Current Research, 
8(8):35752-32756.

Navani, Yogita and Ansari, MA. 2017. Assessing e-learning readiness of University faculty in India. Advances in Computer Science and Information Technology, 4(3): 209-214

Navani, Yogita and Ansari, M.A. 2019. Comparative Analysis of two State Agriculture Universities (PAU-HMAU) in India. Journal of Environmental and Bioscience, Vol. 33 (2): 311-315

Navani, Y. and Ansari, M.A. (2020) Study of E-learning Readiness of Teachers of State Agriculture University. International Journal of Agriculture Sciences, 12( )3: 9508-9512.

Neeru, S. 2009. ICT in Indian Universities and Colleges. Management and Change, 13 (2): 106-114.

Rosenberg, M.J. 2001. E-learning: Strategies for delivering knowledge in the digital age. Boston: McGraw-Hill Professional.
Tahereh, E., Mona, M. and Noor, A. 2010. Assessment of Instructors' readiness for implementing e-learning in $\mathrm{CME}$ in Iran. Medical Teacher, 32:1-10.

UNESCO. 2004. Integrated ICT into Education: Lesson learned. UNESCO Asia and Pacific Regional Bureau for Education, Bangkok, Thailand. Retrieved August 4, 2009, from http://www.gesci.org/ old/files/docman/ICT__integrating _ education.pdf.

Welsh, E., Brown, K. and Simmering, M. 2003. e-Learning: emerging uses, empirical results and future directions. International Journal of Training and Development, 7 (4): 245-258.

Yuen, A. H. K. 2010. Blended learning in higher education: An exploration of teaching approaches. Proceeding of the $18^{\text {th }}$ International Conference on Computers in Education.

\section{How to cite this article:}

Yogita, N. and Ansari, M. A. 2020. A Comparative Study of e-Learning Readiness of Two State Agricultural Universities (SAUs) in Northern India. Int.J.Curr.Microbiol.App.Sci. 9(07): 1137-1149. doi: https://doi.org/10.20546/ijcmas.2020.907.133 